\title{
EVALUATION OF BREAD WHEAT GENOTYPES IN IRRIGATED AND RAINFED CONDITIONS USING BIPLOT ANALYSIS
}

\author{
KARAMAN, M. \\ Department of Plant Production Technologies, Faculty of Applied Sciences \\ Mus Alparslan University, Mus,Turkey \\ (e-mail: karaman2178@hotmail.com; phone:+90-530-600-9136; fax:+90-436-231-2201) \\ (Received 23 $3^{\text {rd }}$ Oct 2018; accepted 20 ${ }^{\text {th }}$ Dec 2018)
}

\begin{abstract}
This study was carried out in 2015-2016 and 2016-2017 seasons under supplemented irrigation (IC) and rainfall conditions (RC) of Diyarbakir in Turkey, was to determine high adaptive yielding with high quality bread wheat genotypes. The obtained data were analyzed using variance and GGE-biplot analysis methods, and the genotypes $(\mathrm{G})$ were evaluated for drought tolerance indices. The average grain yield of two year ranged from 5820 to $6950 \mathrm{~kg} \mathrm{ha}^{-1}$ on rainfall conditions and 7880 to $9050 \mathrm{~kg} \mathrm{ha}^{-1}$ under supplemented irrigation conditions. The GGE biplot graph showed that G3, G6 and G21 were best genotypes for grain yield. Although G23 did not have the highest grain yield, it was determined that it represented the most stable line. Furthermore, G12 and G16 were determined as suitable genotypes for irrigated conditions and G21 for rainfall condition. It was determined that mean productivity (MP), stress tolerant index (STI), geometric mean productivity (GMP) and harmonic mean (HM) parameters were related with Yp (supplemented irrigation yield) and Ys (rainfall condition yield). Also, yield index (YI), drought resistance index (DRI), yield stability index (YSI) was related with Ys. In the study concluded that the lines G6, G12, G16 and G21 could be candidates for registration.
\end{abstract}

Keywords: wheat, drought, GGE-biplot, yield components, stability

\section{Introduction}

Bread wheat (Triticum aestivum L.) is highly adaptable to different ecological areas and has an important role in human nutrition (Dhanda et al., 2004; Nazar et al., 2012). It is reported that the global wheat cultivation is approximately 222.9 million hectares and world wheat production is around 720 million tons by Food Agriculture Organization (FAO, 2015). In Turkey, with a planting area of 7.8 million hectares and production of 22.6 million tons, wheat ranks first in grain production according to Turkish Statistical Institute (TSI, 2015). The rapidly growing world population has made it necessary to increase grain yield per unit area, particularly in light of the gradually reduced agricultural areas. Consumers' expectations concerning the quality of wheat vary; therefore, development of different quality wheat has become a requirement. However, to date, wheat breeding studies have aimed to produce varieties with high grain yield; thus, quality traits desired by the industry and consumers have not been among priority targets. For this reason, wheat imports have increased to meet the high-quality raw material needs of the industry and supply cheap raw materials. In order to keep these imports to a minimum, there is a need to develop new wheat varieties with both the desired quality characteristics and high yield (Erkul, 2006; Yazar et al., 2013).

In Turkey and around the world, wheat cultivation is generally undertaken in rainfed conditions dominated by general drought stress, but in rarer cases, it is also rarely supported by irrigation, which makes it crucial to identify genotypes suitable for both rainfed and irrigated conditions. For this purpose, wheat breeders and agronomists cultivate existing genotypes under both irrigated and rainfed conditions and use the results of these experiments to determine the specific requirements of genotypes based 
on mathematical formulas (Farshadfar, 2012; Aktaş, 2017). In studies investigating the tolerability of drought in durum wheat, it is observed that genotypes with low values for yield stability index (YSI), drought resistance index (DRI) and yield index (YI) parameters favor limited watering conditions whereas those with high values harmonic mean (HM), geometric mean productivity (GMP) and mean productivity (MP) values have higher grain yield potential under conditions of no water stress. (Mohammadi et al., 2011; Nouri et al., 2011).

It has been reported that the effect of drought stress on plant growth and grain yield in wheat is dependent on the stage, severity and duration of drought stress, and the main reason for grain yield loss is the negative effect of drought on spike formation and leaf area duration after flowering (Öztürk, 1999). In wheat breeding programs, the selection parameters for varieties suitable for irrigated conditions include grain yield, number of grains per spike, grain weight per spike, and spike per square meter while those for rainfed conditions are plant height, number of spikes per square meter, and spike length (Ozturk and Korkut, 2018).

In this study, genotypes were tested in two different growing seasons under rainfed and irrigated conditions to determine suitable candidates for cultivation in the Southeastern Anatolia Region of Turkey by taking into account the responses of genotypes to these different conditions and the effects on grain yield, quality, yield, and yield components.

\section{Materials and methods}

In this study, 20 advanced lines were used as material and five registered varieties intensely cultivated in the Southeastern Anatolia Region in Turkey were utilized as standard (Table 1). The experiments were based on a randomized block design with four replications (R), and were conducted in Diyarbakır province, Turkey $\left(37^{\circ} 56^{\prime} \mathrm{N}\right.$; $40^{\circ} 15^{\prime} \mathrm{E}$; $599 \mathrm{~m}$ altitude) under irrigated and rainfed conditions in the 2015-16 and 2016-17 growing seasons (Figure 1).

First year, trials were planted on November 11. Harvest was made on June 11 and June 26 in rainfall and irrigation conditions respectively. Second year, trials were planted on November 10. Harvest was made on June 20 and July 01 in rainfall and irrigation conditions respectively. In irrigated trials, the plants were irrigated once at the end of flowering period. It was used $100 \mathrm{~mm}$ water per square meter with keel irrigation method. Sowing was performed on parcels of $6 \mathrm{~m}^{2}, 450$ seeds per square meter using a sowing machine. Fertilization was under taken with $60 \mathrm{~kg} \mathrm{ha}^{-1}$ pure nitrogen $(\mathrm{N})$ and 60 $\mathrm{kg} \mathrm{ha}^{-1}$ pure phosphorus $\left(\mathrm{P}_{2} \mathrm{O}_{5}\right)$ during sowing and $80 \mathrm{~kg} \mathrm{ha}^{-1}$ nitrogen $(\mathrm{N})$ during the tillering period. Harvest was by plot combine harvester. In the area where the experiment was carried out, the soil characteristics were determined as follows: texture $=$ clay, $\mathrm{pH}=7.87$ (slightly alkaline), organic matter ratio $=0.86 \%$, salt ratio $=0.32$, and lime ratio $\left(\mathrm{CaCO}_{3}\right)=8.12 \% \mathrm{~kg} \mathrm{da}^{-1}$. The total amount of rainfall was $417 \mathrm{~mm}$ and 453 $\mathrm{mm}$ in the first and second growing seasons of the study (Table 2). Both of these values were lower than the long-term average amount of rain $(482 \mathrm{~mm})$ (Anonim, 2017). Protein ratio (\%) was determination according to (NIR) AACC 39-10 (Anonymous, 1990). Measurement of the spikes per square meter was made over $1 \mathrm{~m}$ length and 20 $\mathrm{cm}$ width on a row, then multiplied by 5 to calculate the spike number in the area of 1 square meter. 
Table 1. Pedigree and Origin of Bread Wheat Genotypes Used in The Study

\begin{tabular}{|c|c|c|c|}
\hline Genotypes & Symbol & Pedigree & $\begin{array}{c}\text { Breeding } \\
\text { Institution or } \\
\text { Origin }\end{array}$ \\
\hline 1 & G1 & $\begin{array}{c}\text { Worrakatta/2*Pastor//Danphe \#1 Cmsa07m00403s-040ztm- } \\
\text { 040zty-15ztm-010y-01b-0ymxi11-12\M21sawytl41 }\end{array}$ & CIMMYT \\
\hline 2 & $\mathrm{G} 2$ & $\begin{array}{l}\mathrm{Ka} / \mathrm{Nac} / / \mathrm{Trch} / 3 / \mathrm{Danphe} \# 1 \text { Cmsa07m00445s-040m-0nj-0nj-4y- } \\
\text { 0b Mxi11-12〈M21 sawyt } \backslash 112\end{array}$ & CIMMYT \\
\hline 3 & G3 & $\begin{array}{c}\text { Bav92//Irena/Kauz/3/Huites/4/2*Rolf07 Cmss06y00875t- } \\
\text { 099Topm-099y-099ztm-099y-099m-25wgy-0b Mxi11- } \\
\text { 12\Msawyt 132 }\end{array}$ & CIMMYT \\
\hline 4 & G4 & $\begin{array}{c}\text { Fret2/Tukuru//Fret2/3/Munia/Chto//Amsel/4/Fret2/Tukuru//Fret2 } \\
\text { Cmss06y00878t-099topm-099y-099ztm-099y-099m-17wgy-0b } \\
\text { Mxi11-12lMsawyt133 }\end{array}$ & CIMMYT \\
\hline Dinç & G5 & Check & $\begin{array}{l}\text { GAP UTAEM in } \\
\text { Turkey }\end{array}$ \\
\hline 6 & G6 & $\begin{array}{l}\text { Wbll1/Fret2//Pastor*2/3/Murga Cmss06y00937t-099topm-099y- } \\
\text { 099ztm-099y-099m-10wgy-0b Mxi11-12\Msawyt144 }\end{array}$ & CIMMYT \\
\hline 7 & G7 & $\begin{array}{l}\text { Frncln*2/Tecue \#1 Cmss07y00941t-099topm-099y-099m-099y- } \\
\text { 11m-0wgy Mxi11-12\M34eswyt167 }\end{array}$ & CIMMYT \\
\hline 8 & G8 & Ceyhan99//Tuj"s"/Onelto See06032 & CIMMYT \\
\hline 9 & G9 & $\begin{array}{l}\text { Bav92//Irena/Kauz/3/Huites/4/Doll Cmss05b00188s-099y-099m- } \\
\text { 099y-099ztm-18wgy-0b }\end{array}$ & CIMMYT \\
\hline Pehlivan & G10 & Check & $\begin{array}{l}\text { TTAEM in } \\
\text { Turkey }\end{array}$ \\
\hline 11 & G11 & $\begin{array}{l}\text { Attila/Bav92//Pastor/3/Attila*2/Pbw65 Cmsa04m00070s-040ztb- } \\
\text { 040zty-040ztm-040sy-13ztm-04y-0b }\end{array}$ & CIMMYT \\
\hline 12 & G12 & $\begin{array}{c}\text { Cunningham/4/Sni/Trap\#1/3/Kauz*2/Trap//Kauz } \\
\text { Cmsa04m00088s-040ztb-040zty-040ztm-040sy-3ztm-01y-0 }\end{array}$ & CIMMYT \\
\hline 13 & G13 & $\begin{array}{l}\text { Sokoll/Excalibur Cmsa04y00612s-25ztp0y-010m-010sy-4m-03y- } \\
\text { 0b }\end{array}$ & CIMMYT \\
\hline 14 & G14 & $\begin{array}{l}\text { Wbll1*2/Kkts//Pastor/Kukunacmss05b00525s-099y-099m-099y- } \\
\text { 099ztm-3wgy-0b }\end{array}$ & CIMMYT \\
\hline Aday-12 & G15 & Check & $\begin{array}{l}\text { GAP UTAEM in } \\
\text { Turkey }\end{array}$ \\
\hline 16 & G16 & $\begin{array}{l}\mathrm{Kachu} / 5 / \mathrm{Nac} / \mathrm{Th} . \mathrm{Ac} / / 3 * \mathrm{Pvn} / 3 / \mathrm{Mirlo} / \mathrm{Buc} / 4 / 2 * \text { Pastor } \\
\text { Cmss05b00584s-099y-099m-099y-099ztm-8wgy-0b }\end{array}$ & CIMMYT \\
\hline 17 & G17 & $\begin{array}{l}\text { B.Hashi+B764ta/5/Dove/Inia/4/4777/(2)//Fkn/Gb/3/Pvn } \\
\text { See060149-0s-0s-0sd }\end{array}$ & CIMMYT \\
\hline 18 & G18 & $\begin{array}{c}\text { Krichauff/2*Pastor/4/Milan/Kauz//Prinia/3/Bav92 } \\
\text { Cmsa06y00337s-040ztp0y-040ztm-040p0y-4ztm-0y-0b }\end{array}$ & CIMMYT \\
\hline 19 & G19 & $\begin{array}{l}\text { Heilo//Sunco/2*Pastorcmsa06y00492s-040zty-040ztm-040sy- } \\
\text { 2ztm-0y-0b }\end{array}$ & CIMMYT \\
\hline Tekin & G20 & Check & $\begin{array}{l}\text { GAP UTAEM in } \\
\text { Turkey }\end{array}$ \\
\hline 21 & G21 & Frncln/Rolf07cmss06b00013s-0y-099ztm-099y-099m-2wgy-0b & CIMMYT \\
\hline 22 & G22 & $\begin{array}{c}\text { Becard/Kachu Cmss06b00169s-0y-099ztm-099y-099m-28wgy- } \\
\text { 0b }\end{array}$ & CIMMYT \\
\hline 23 & $\mathrm{G} 23$ & $\begin{array}{c}\text { Rolf07*2/5/Reh/Hare//2*Bcn/3/Croc_1/Ae.Squarrosa } \\
(213) / / \text { Pgo/4/Huites Cmss06b00704t-099topy-099ztm-099y- } \\
\text { 099m-23wgy-0b }\end{array}$ & CIMMYT \\
\hline 24 & $\mathrm{G} 24$ & $\begin{array}{l}\text { Usher-16 Crow's'/Bow's'-1994/95//Asfoor-5 Icw01-00257-0ap- } \\
\text { 8ap-0ap/0ts-0ap-12ap-0ap }\end{array}$ & CIMMYT \\
\hline Ceyhan-99 & G25 & Check & $\begin{array}{l}\text { DATAE in } \\
\text { Turkey }\end{array}$ \\
\hline
\end{tabular}




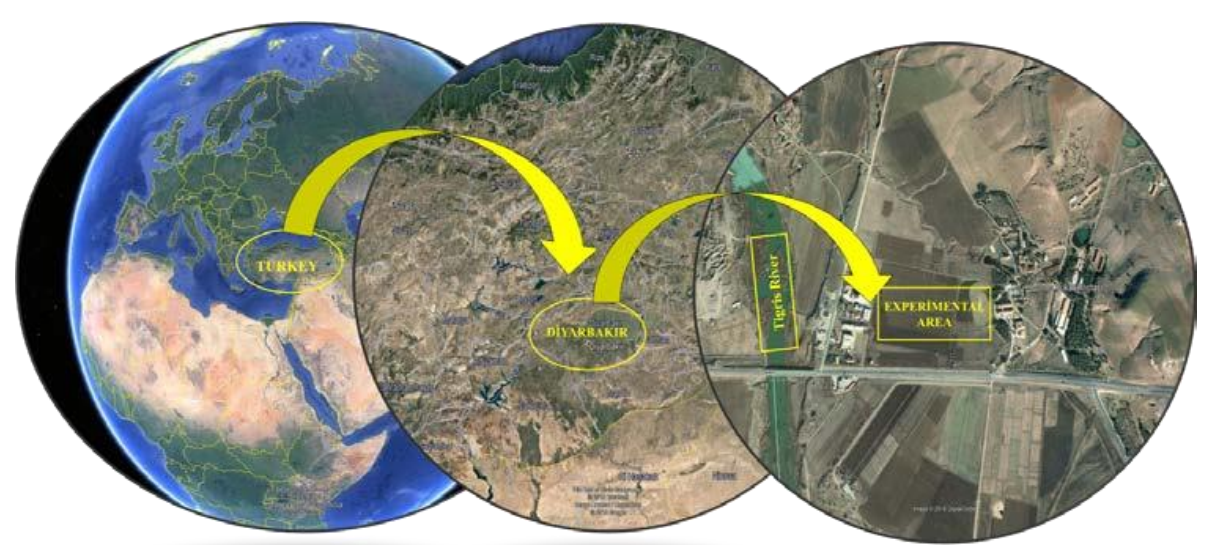

Figure 1. Experimental Area (US Dep of State Geopraphy (C) 2018 Google image landset/Copernics)

Table 2. Climate data province of 2015-2016 and 2016-2017 wheat growing season in Diyarbakır

\begin{tabular}{c|ccc|ccc}
\hline \multirow{2}{*}{ Month } & \multicolumn{3}{|c|}{ Average of Temperature $\left({ }^{\mathbf{0}} \mathbf{C}\right)$} & \multicolumn{3}{c}{ Precipitation (mm) } \\
\cline { 2 - 7 } & $\mathbf{2 0 1 5 - 2 0 1 6}$ & $\mathbf{2 0 1 6 - 2 0 1 7}$ & Long-Term & $\mathbf{2 0 1 5 - 2 0 1 6}$ & $\mathbf{2 0 1 6 - 2 0 1 7}$ & Long-Term \\
\hline September & 27.4 & 24.2 & 24.8 & 0.0 & 5.2 & 4.1 \\
October & 18.4 & 18.8 & 17.2 & 84.2 & 13.6 & 34.7 \\
November & 9.8 & 8.2 & 9.2 & 10.4 & 52.0 & 51.8 \\
December & 3.9 & 2.4 & 4.0 & 31.6 & 135.6 & 71.4 \\
January & 1.1 & 1.5 & 1.8 & 77.2 & 20.6 & 68.0 \\
February & 7.9 & 1.5 & 3.5 & 69.2 & 3.8 & 68.8 \\
March & 9.7 & 9.4 & 8.5 & 55.6 & 90.2 & 67.3 \\
April & 15.7 & 12.8 & 13.8 & 29.0 & 98.8 & 68.7 \\
May & 19.9 & 18.8 & 19.3 & 41.4 & 30.6 & 41.3 \\
June & 26.8 & 26.9 & 26.3 & 18.4 & 2.6 & 7.9 \\
\hline Total & \multicolumn{7}{c}{}
\end{tabular}

Drought tolerance parameters were calculated using the following formulas (Equation $=1,2,3,4,5,6,7$ and 8) developed by previous researchers:

Stress tolerant index (Fernandez, 1992):

$$
(\mathrm{STI})=(\mathrm{Yp} * \mathrm{Ys}) / \overline{\mathrm{Y}} \mathrm{p}^{2}
$$

Tolerance (Hossain et al., 1990):

$$
(\mathrm{TOL})=\mathrm{Yp}-\mathrm{Ys}
$$

Geometric Mean Productivity (Fernandez, 1992):

$$
(\mathrm{GMP})=\sqrt{ }(\mathrm{Yp} * \mathrm{Ys})
$$

Mean Productivity (Rosielle and Hambline, 1981):

$$
(\mathrm{MP})=(\mathrm{Yp}+\mathrm{Ys}) / 2
$$


Harmonic Mean (Chakherchaman et al., 2009):

$$
(\mathrm{HM})=2 *(\mathrm{Yp} * \mathrm{Ys}) /(\mathrm{Yp}+\mathrm{Ys})
$$

Yield Stability Index (Bouslama and Schapaugh, 1984):

$$
(\mathrm{YSI})=\mathrm{Ys} / \mathrm{Yp}
$$

Yield Index (Gavuzzi et al., 1997):

$$
(\mathrm{YI})=\mathrm{Ys} / \mathrm{Y} \mathrm{s}
$$

Drought Resistance Index (Lan, 1998):

$$
(\mathrm{DRI})=\mathrm{Ysx}(\mathrm{Ys} / \mathrm{Yp}) / \bar{Y}_{\mathrm{s}}
$$

\section{Statistical analysis of data}

An analysis of variance (ANOVA) was performed using JMP 5.0 software and genotype by environment interaction (GGE) biplot analysis using GenStat statistical package program 12th Edition (GenStat, 2009). The differences between the averages were examined by a least significant difference (LSD) test $(\mathrm{p}<0.01$ and $\mathrm{p}<0.05)$ (Gomez and Gomez, 1984).

\section{Results and discussion}

The ANOVA analysis revealed statistically significant differences in the mean grain yield and other quality traits between rainfed (Ys) and irrigated (Yp) conditions ( $\mathrm{p}$ $<0.01$ and $\mathrm{p}<0.05)$ (Table 3).

\section{Grain yield (GY) $\left(\mathrm{kg} \mathrm{ha}^{-1}\right)$}

According to the results of ANOVA, year, genotype and genotype*year were found to have a statistically significant effect $(\mathrm{p}<0.01)$ on grain yield in both rainfed and irrigated conditions. The mean grain yield over the two growing seasons was $8520 \mathrm{~kg}$ $\mathrm{ha}^{-1}$ and $6080 \mathrm{~kg} \mathrm{ha}^{-1}$ for irrigated and rainfed trails, respectively. The highest grain yield was obtained from G12 (9050 kg ha-1) and G16 (9010 kg ha-1) in irrigated trials and G21 (6950 kg ha $\left.{ }^{-1}\right)$ in rainfed conditions. It has previously been reported that the main factor affecting yield in wheat is the genetic structure of the plant (Gebeyehou et al., 1982). Therefore, genotypes should be evaluated in different environments; i.e., in multiple locations or over different years to determine the grain yield potential. Not only hereditary but also abiotic and biotic stress factors have a role in the variation of genotype responses in different climates and soil structures. High or low levels of precipitation and higher or lower temperatures further increase the effect of GGE (Blum, 1998; Chamurliyski et al., 2015; Kılıç et al., 2018). However, grain yield in wheat is more affected by the distribution of rainfall throughout the growing season, rather than the total amount of precipitation (Çetin et al., 1999). 
Table 3. Results of variance analysis

\begin{tabular}{|c|c|c|c|c|c|c|c|c|c|c|}
\hline \multicolumn{11}{|c|}{ Rainfall Conditions } \\
\hline \multicolumn{11}{|c|}{ Squares Mean } \\
\hline Resources & DF & GY & HW & TGW & PR & ZS & SPSM & SL & FSPS & GPS \\
\hline $\mathrm{Y}$ & 1 & $163947^{* *}$ & $653.6^{* *}$ & $1693.46^{* *}$ & $15.71^{\text {** }}$ & $14413.4^{* *}$ & $6042.9^{* *}$ & $0.1^{\text {n.s }}$ & $2.0^{\text {n.s }}$ & $189.2^{*}$ \\
\hline $\mathrm{R}[\mathrm{Y}]$ & 6 & $69803.6^{* *}$ & $2.9^{\text {n.s }}$ & $0.67^{\mathrm{n} . \mathrm{s}}$ & $0.07^{\text {n.s }}$ & $24.5^{\mathrm{n} . \mathrm{s}}$ & $112.08^{\text {n.s }}$ & $1.4^{\mathrm{n} . \mathrm{s}}$ & $5.6^{\mathrm{n} . \mathrm{s}}$ & $12.9^{*}$ \\
\hline G & 24 & $233534^{* *}$ & $358.7^{* *}$ & $643.05^{* *}$ & $34.13^{\text {n.s }}$ & $946.54^{* *}$ & $7227.7^{* *}$ & $69.2^{* *}$ & $86.9^{* *}$ & $2809.1^{\mathrm{n} . \mathrm{s}}$ \\
\hline $\mathrm{Y} * \mathrm{G}$ & 24 & $237439^{* *}$ & $67.2^{\text {n.s }}$ & $132.96^{\text {n.s }}$ & $9.72^{\text {n.s }}$ & $946.54^{* *}$ & $7529.8^{* *}$ & $17.8^{\mathrm{n} . \mathrm{s}}$ & $39.3^{\text {n.s }}$ & $2816.1^{* *}$ \\
\hline $\mathrm{CV}(\%)$ & & 6.9 & 1.9 & 6.8 & 7.8 & 8.6 & 7.9 & 7.2 & 6.2 & 13.9 \\
\hline \multicolumn{11}{|c|}{ Irrigation Conditions } \\
\hline \multicolumn{11}{|c|}{ Squares Mean } \\
\hline Resources & DF & GY & HW & TGW & PR & $\mathbf{Z S}$ & SPSM & SL & FSPS & GPS \\
\hline $\mathrm{Y}$ & 1 & $63937.7^{* *}$ & $145.2^{* *}$ & $764.8^{* *}$ & $0.02^{\mathrm{ns}}$ & $331.2^{* *}$ & $3433.9^{* *}$ & $3.9^{\text {ns }}$ & $20.4^{\mathrm{ns}}$ & $12.8^{\mathrm{ns}}$ \\
\hline $\mathrm{R}[\mathrm{Y}]$ & 6 & $8141.8^{\mathrm{ns}}$ & $0.34^{\mathrm{ns}}$ & $0.4^{\mathrm{ns}}$ & $0.02^{\mathrm{ns}}$ & $11.7^{\mathrm{ns}}$ & $15.8^{\mathrm{ns}}$ & $1.4^{\mathrm{ns}}$ & $4.5^{\mathrm{ns}}$ & $87.6^{\mathrm{ns}}$ \\
\hline $\mathrm{G}$ & 24 & $176936^{* *}$ & $139.4^{* *}$ & $564.4^{* *}$ & $18.9^{*}$ & $1530.9^{* *}$ & $6958.6^{*}$ & $34.6^{* *}$ & $63.1^{* *}$ & $1896.3^{\mathrm{ns}}$ \\
\hline $\mathrm{Y}^{*} \mathrm{G}$ & 24 & $316624^{* *}$ & $6.7^{\mathrm{n} . \mathrm{s}}$ & $99.1^{* *}$ & $15.6^{*}$ & $297.8^{* *}$ & $5772.0^{\mathrm{ns}}$ & $27.9^{*}$ & $25.5^{\text {n.s }}$ & $1671.5^{\mathrm{ns}}$ \\
\hline $\mathrm{CV}(\%)$ & & 4.2 & 0.5 & 3.5 & 4.6 & 5.8 & 11.3 & 7.6 & 5.4 & $15.3^{\text {n.s }}$ \\
\hline
\end{tabular}

GY: Grain yield, HW: Hectoliter weight, TGW: Thousand grain weight, PR: Protein ratio, ZS: Zeleny sedimentation, SPSM: Number of spikes per square meter, SL: Spike length, FSPS: Number of fertile spikelets per spike, GPS: Number of grains per spike, DF: Degree of freedom, R: Replication, Y: Year, G: Genotype **: Statistically significant at $0.01, *$ : Statistically significant at 0.05 , ns: not significant 


\section{Hectoliter weight (HW) $\left(\mathrm{kg} \mathrm{hl}^{-1}\right)$}

ANOVA revealed statistically significant differences between growing seasons and genotypes in terms of mean HW under rainfed and irrigated conditions $(p<0.01)$. Considering the mean values obtained from the two growing seasons, Tekin variety had the highest HW (84.8-81.7 $\mathrm{kg} \mathrm{hl}^{-1}$ ) under both experimental conditions. This trait is influenced by several factors, such as environment, physical properties of grain (e.g., homogeneity and endosperm cavity), and endosperm structure. Studies conducted in this area have reported that HW varies according to hereditary factors (Genç et al., 1993) and different climatic conditions (Atlı et al., 1993).

\section{Thousand grain weight (TGW) (g)}

According to the two-year average values, the highest TGW values were obtained from the Pehlivan (42.9 g) and Aday-12 (42.7 g) standards in irrigated trials and from the G3 (34.2 g) under rainfed conditions. Flour industrialists attach special importance to TGW since there is a significant positive correlation between this trait and flour yield (Yazar et al., 2013). Despite the consensus on the significant correlation between TGW and quality and grain yield, there are contradictory results concerning the direction of this correlation, with some researchers suggesting that it is positive (Bohac and Cermin, 1969; Knott and Talukdar, 1971) while others reporting a negative correlation (Thorne, 1966). In the current study, TGW was found to have a positive correlation with HW and negative correlation with protein ratio (PR) and zeleny sedimentation (ZS).

\section{Protein ratio $(P R)(\%)$}

The mean PR was calculated as $13.1 \%$ and $14.5 \%$ for irrigated and rainfed conditions, respectively. This indicates that PR is affected by not only environmental conditions but also hereditary factors. While the highest PR belonged to G13 in irrigated conditions, for rainfed trials, no significant difference was observed between the protein ratios of genotypes. In Turkey, it has been reported that protein content of wheat varies ranging between 6 and 22\% depending on type, variety, environmental factors, and cultivation conditions (Doğan and Kendal, 2013). These ranges are in agreement with the results obtained in the current study concerning PR. Similarly, in another study conducted in Konya, Turkey, PR in bread wheat was found to vary between 12.62 and $14.16 \%$ in rainfed conditions, and 11.53 and $13.85 \%$ in irrigated conditions (Şahin et al., 2008; Aydoğan and Soylu, 2017).

\section{Zeleny sedimentation (ZS) (ml)}

Year, genotype, and year $\mathrm{x}$ genotype interactions had a statistically significant effect on ZS under rainfed and irrigated conditions $(\mathrm{p}<0.01)$. Sedimentation is of great importance in determining protein quality in wheat (Peterson et al., 1992). In this study, the highest ZS value was obtained from G6 and G17 genotypes in irrigated conditions and from G6 in rainfed conditions. Ozturk and Aydin (2004) reported the sedimentation values in different environments as $32.2 \mathrm{ml}$ for irrigated, 35.7 for rainfed, $34.0 \mathrm{ml}$ for early water stress, $35.0 \mathrm{ml}$ for late water stress and $37.5 \mathrm{ml}$ for continuous water stress conditions. Compared to their study, we found similar values in irrigated conditions but higher values in rainfed conditions. This is considered to be due to environmental conditions and differences in plant material. 


\section{Spikes per square meter (SPSM) (Number)}

There were statistically significant differences between years and genotypes in terms of SPSM in both rainfed and irrigated conditions $(\mathrm{p}<0.01$ or $\mathrm{p}<0.05)$. The highest number of SPSM was observed in genotype G21 in irrigated trials and G9 in rainfed conditions. Researchers have previously reported that the number of SPSM varies according to sowing norms, variety, sowing time, available water, and climate and soil conditions (Kılıç et al., 2010; Kızılgeçi et al., 2016). Although heredity also has a significant role in determining SPSM, this parameter is also influenced by resistance of genotypes to adverse environmental conditions, such as temperature, drought stress, and frost. Studies conducted in various environments suggested that to achieve favorable results concerning grain yield, genotypes having high potential of a greater number of SPSM should be selected (Öztürk and Akten, 1999; Sönmez et al., 1999; Erekul and Köhn, 2006; Karaman, 2017).

\section{Spike length $(S L)(\mathrm{cm})$}

Genotypes G6 and G9 ranked first in terms of SL under irrigated and rainfed conditions, respectively. Aydoğan and Soylu (2017) reported the average SL from their rainfed experiments as $9.75 \mathrm{~cm}$. Similarly, our average measurement of SL was $10.4 \mathrm{~cm}$ for rainfed trials; however, we observed that SL was shorter in irrigated conditions (9.9 $\mathrm{cm})$. This may be attributed to genotypes producing more tillers under irrigation.

\section{Fertile spikelet per spike (FSPS) (Number)}

FSPS statistically significantly differed between genotypes under irrigated and rainfed conditions $(\mathrm{p}<0.01)$. The highest number of FSPS was seen in the Pehlivan variety in irrigated trials whereas for rainfed conditions, many genotypes were included in the same group despite the differences in FSPS. In one of the two previous studies on bread wheat, it was shown that the number of FSPS ranged from 16 to 21 (Genç, 1974), while the other reported no statistically significant difference in this parameter with the values varying between 18.5 and 21.1 (Karaman, 2013).

\section{Grains per spike (GPS) (Number)}

According under rainfed conditions, the number of GPS was statistically significantly affected by year $(\mathrm{p}<0.05)$ and year* genotype interaction $(\mathrm{p}<0.01)$, and the highest value was identified in genotype G9. It has been reported that in wheat, a sufficient amount of nutrients is accumulated in grain after fertilization and greater grain yield is obtained from varieties with a higher number of GPS (Y1ldırım et al., 2005). In another study conducted with 14 bread wheat varieties under rainfed conditions in Konya, it was found that the number of GPS ranged from 31.2 to 44.9 and the average of all trials was 37.9 (Aydoğan and Soylu, 2017). In the current study, the average number of GPS was higher (53.5) in rainfed conditions, which may be due to the differences in genotypes and agronomic applications.

\section{Evaluation of yield and other investigated traits using GGE-biplot analysis}

It has been reported that GGE biplot analysis is very important because it presents the genotype environmental interaction visually (Kendal, 2015; Sayar, 2017). Figures 2 to 5 present the results of GGE-biplot analysis of grain yield (Tables 4 and 5) and other traits of 25 bread wheat genotypes evaluated in the 2015-16 and 2016-17 growing 
seasons under irrigated (IC1, IC2) and rainfed (RC1 and RC2) conditions. The analysis of grain yield revealed that the total variation was $73.38 \%$, of which $44.99 \%$ was explained by principal component 1 (PC1) and $28.39 \%$ by PC2 (Figure 2 and Figure 3). According to the results of GGE-biplot analysis, the highest grain yield belonged to G3, G6 and G21 in RC1; G3, G7, G11, G21 and G23 in IC1; G1 and Dinç in RC2; and G1, G2, G12 and G16 in IC2. Furthermore, genotypes located closer to the center of the axis had values similar to the experimental mean (Figure 2).

In the biplot graph demonstrating the stability capabilities of genotypes (Figure 3), The G3 line located at the far right of the line dividing the graph has the highest grain yield, and the G6, G7, G21 and G23 lines appear to be more prominent than the remaining genotypes concerning grain yield. Although G23 did not have the highest grain yield, it was determined that it represented the most stable line. Furthermore, based on the results IC1 can be considered as the environment that provided the best conditions for genotypes to demonstrate their potential.

If the angle of the vector was less than $90^{\circ}$, there was a positive correlation between the features, if the angle is more than $90^{\circ}$ there is no correlation between features (Yan and Thinker, 2006; Dogan et al., 2016; Oral, 2018). As revealed by the biplot graph showing the correlations between genotype traits under rainfed conditions (Figure 4), GY was positively correlated with SL, FSPS, TGW and HW; and SPSM with ZS, GPS and PR; whereas PR had a negative correlation with TGW and HW. Furthermore, G6 and G21 were more prominent for GY; G8 and Tekin for HW; G3 and Pehlivan for TGW; G6 and G23 for ZS; G9, G11 and G21 for SPSM; G6 and G9 for SL; G6, G8, G11, G14 and Pehlivan for FSPS; and G9 and G11 for GPS.

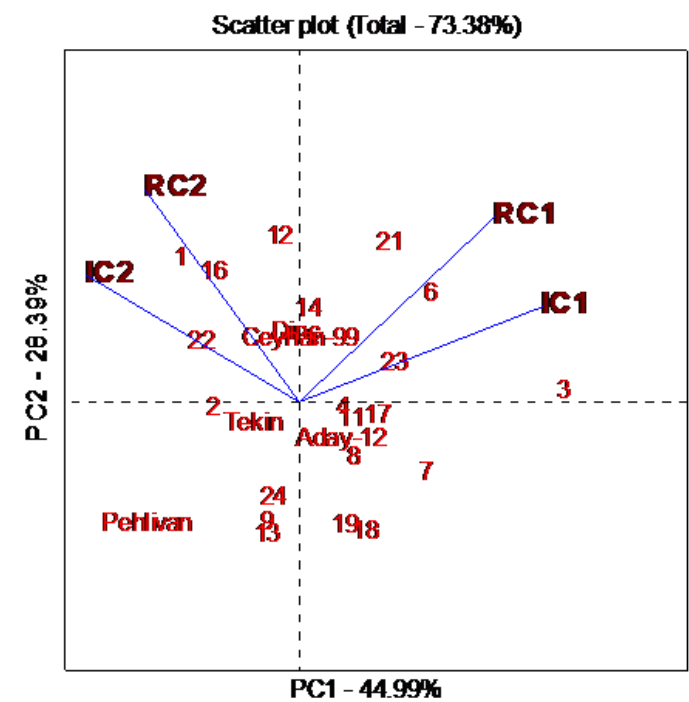

Figure 2. GGE-biplot of grain yield

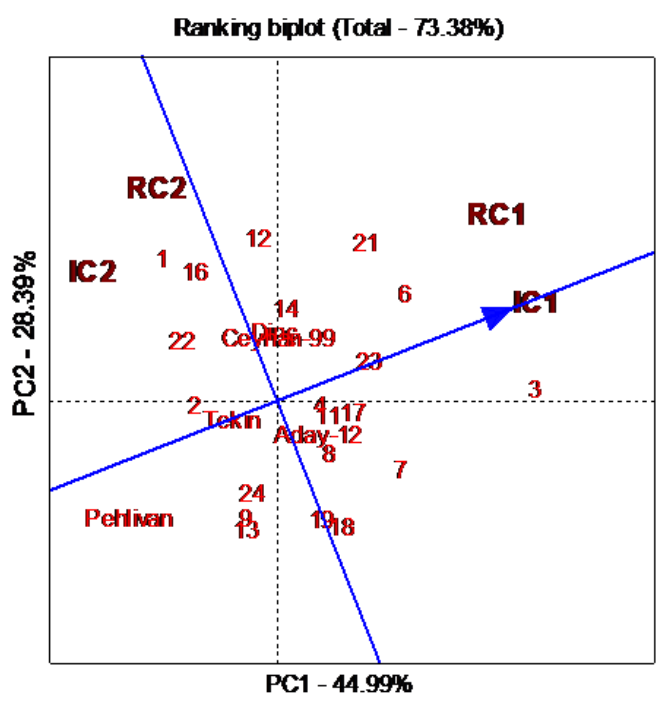

Figure 3. Stability of genotypes in terms of grain yield

For all parameters, the lines closer to the center of the axis showed similar values to the experimental average. According to the biplot graph showing the relationship between the genotype traits under irrigated conditions (Figure 5), there was a significant positive relationship between TGW and SL and FSPS; GY and GPS; SPSM, ZS and PR, and a significant negative correlation between HW, SPSM, PR and ZS. Under these conditions, the most promising genotypes were found to be G3, G12 and G16 for GY; 
G18 and Tekin for HW; G8, Pehlivan and Aday-12 for TGW; G13 and G21 for PR; G1, G6, G17 and G23 for ZS; G21 and G24 for SPSM; G4, G6 and G18 for SL; and G6, Pehlivan, Aday-12 and G24 for FSPS; G9 and G23 had values similar to the average.

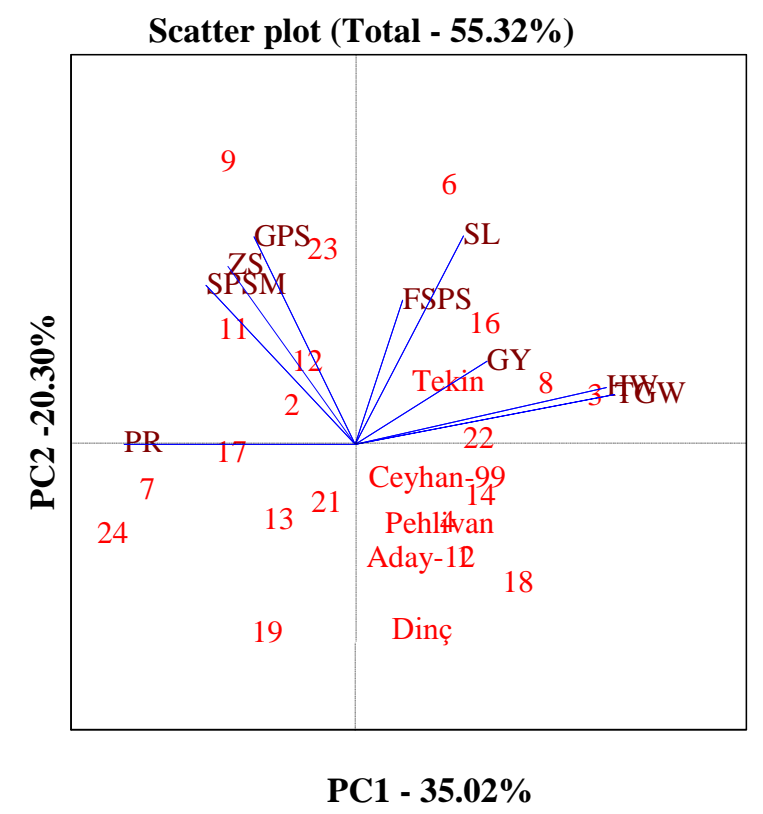

Figure 4. Biplot graph of genotype trait correlations in rainfed conditions

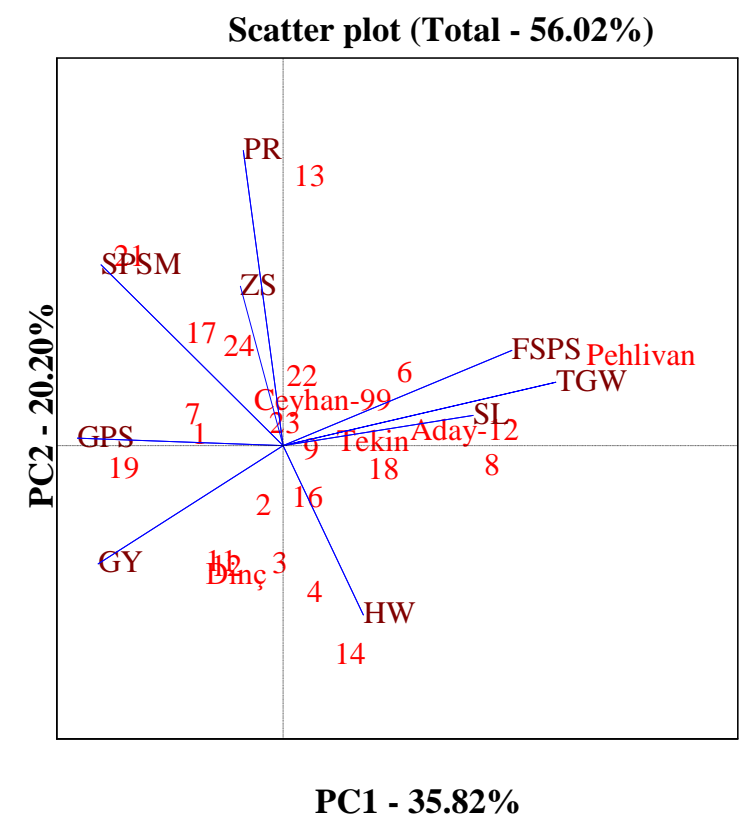

Figure 5. Biplot graph of genotype trait correlations in irrigated conditions 
Table 4. The mean grain yield values obtained from the 2015-16 and 2016-17 growing seasons

\begin{tabular}{|c|c|c|c|c|c|c|c|c|c|c|c|c|c|c|c|}
\hline & \multicolumn{4}{|c|}{ 2015-16 $\left(\mathrm{kg} \mathrm{ha}^{-1}\right)$} & \multicolumn{6}{|c|}{ 2016-17 (kg ha-1) } & \multicolumn{5}{|c|}{ Average of two seasons $\left(\mathrm{kg} \mathrm{ha}^{-1}\right)$} \\
\hline & \multicolumn{2}{|c|}{ IC1 } & \multicolumn{2}{|c|}{ RC1 } & \multirow{2}{*}{$\begin{array}{c}\text { \% Lost } \\
14\end{array}$} & \multirow{2}{*}{$\begin{array}{l}\text { IC2 } \\
9160\end{array}$} & \multicolumn{3}{|c|}{ RC2 } & \multirow{2}{*}{$\begin{array}{c}\text { \% Lost } \\
26\end{array}$} & \multirow{2}{*}{$\begin{array}{c}\text { IC } \\
8480\end{array}$} & \multicolumn{2}{|c|}{ RC } & \multicolumn{2}{|c|}{ \% Lost } \\
\hline G1 & 7810 & f-h & 6720 & c-e & & & $\mathrm{ab}$ & 6820 & $\mathrm{a}$ & & & $\mathrm{d}-1$ & 6770 & $a-c$ & 20 \\
\hline G2 & 7230 & $1 \mathrm{j}$ & 6870 & $b-d$ & 5 & 9160 & $a b$ & 5740 & h-1 & 37 & 8190 & $h-j$ & 6300 & d-h & 23 \\
\hline G3 & 9600 & $\mathrm{a}$ & 7700 & $\mathrm{a}$ & 20 & 8230 & gh & 5170 & $\mathrm{~m}$ & 37 & 8910 & $a b$ & 6440 & $c-g$ & 28 \\
\hline G4 & 8830 & $\mathrm{bc}$ & 6610 & $c-f$ & 25 & 8890 & a-e & 5620 & $\mathrm{j}-\mathrm{m}$ & 37 & 8860 & $\mathrm{a}-\mathrm{c}$ & 6110 & $g-1$ & 31 \\
\hline Dinç & 8540 & b-e & 6390 & $\mathrm{c}-\mathrm{g}$ & 25 & 8560 & $\mathrm{c}-\mathrm{g}$ & 6730 & $\mathrm{ab}$ & 21 & 8550 & $\mathrm{c}-\mathrm{g}$ & 6560 & $a-f$ & 23 \\
\hline G6 & 8580 & b-e & 7810 & $\mathrm{a}$ & 9 & 8410 & $e-h$ & 6050 & $d-j$ & 28 & 8500 & $\mathrm{~d}-1$ & 6930 & $a b$ & 18 \\
\hline G7 & 8940 & $\mathrm{~b}$ & 6650 & $c-f$ & 26 & 8250 & gh & 5550 & $j-m$ & 33 & 8590 & $b-f$ & 6100 & $g-1$ & 29 \\
\hline G8 & 7780 & gh & 6820 & b-d & 12 & 7980 & $\mathrm{~h}$ & 6130 & $c-1$ & 23 & 7880 & $\mathrm{j}$ & 6480 & $c-g$ & 18 \\
\hline G9 & 7920 & $f-h$ & 5960 & f-h & 25 & 8500 & d-g & 5830 & g-1 & 31 & 8210 & $g-j$ & 5890 & h1 & 28 \\
\hline Pehlivan & 6830 & $\mathrm{j}$ & 5690 & $\mathrm{~h}$ & 17 & 9040 & $a-c$ & 5980 & e-k & 34 & 7930 & $\mathrm{j}$ & 5830 & 1 & 27 \\
\hline G11 & 8930 & $\mathrm{~b}$ & 6200 & d-h & 31 & 8350 & $f-h$ & 6240 & $b-h$ & 25 & 8640 & $b-f$ & 6220 & $e-1$ & 28 \\
\hline G12 & 8790 & b-d & 6950 & $\mathrm{bc}$ & 21 & 9310 & $\mathrm{a}$ & 6370 & $a-f$ & 32 & 9050 & $\mathrm{a}$ & 6660 & $a-d$ & 26 \\
\hline G13 & 7590 & h1 & 6270 & $c-h$ & 17 & 8780 & $b-f$ & 5400 & $\operatorname{lm}$ & 39 & 8180 & $\mathrm{ij}$ & 5830 & 1 & 29 \\
\hline G14 & 8510 & b-e & 6840 & b-d & 20 & 8800 & $b-f$ & 6380 & $a-f$ & 27 & 8650 & $b-f$ & 6610 & a-e & 24 \\
\hline Aday-12 & 8280 & d-g & 6500 & $c-g$ & 22 & 8800 & $b-f$ & 5720 & $1-1$ & 35 & 8540 & $c-h$ & 6110 & $g-1$ & 28 \\
\hline G16 & 8650 & b-d & 6360 & $\mathrm{c}-\mathrm{h}$ & 26 & 9380 & $\mathrm{a}$ & 6540 & $a-d$ & 30 & 9010 & $\mathrm{a}$ & 6450 & $c-g$ & 28 \\
\hline G17 & 8820 & $\mathrm{bc}$ & 6780 & b-d & 23 & 8790 & $b-f$ & 5500 & $\mathrm{k}-\mathrm{m}$ & 37 & 8800 & $a-d$ & 6140 & $f-1$ & 30 \\
\hline G18 & 8450 & b-e & 6250 & $c-h$ & 26 & 8370 & $f-h$ & 5460 & $k-m$ & 35 & 8410 & $e-1$ & 5860 & 1 & 30 \\
\hline G19 & 8530 & b-e & 6070 & e-h & 29 & 8430 & e-h & 5580 & $j-m$ & 34 & 8480 & $d-1$ & 5820 & 1 & 31 \\
\hline Tekin & 7900 & $\mathrm{f}-\mathrm{h}$ & 6170 & d-h & 22 & 8700 & b-g & 6300 & b-g & 28 & 8300 & $f-1$ & 6230 & $\mathrm{~d}-1$ & 25 \\
\hline G21 & 8930 & $\mathrm{~b}$ & 7430 & $a b$ & 17 & 8610 & c-g & 6470 & a-e & 25 & 8770 & $a-d$ & 6950 & $\mathrm{a}$ & 21 \\
\hline G22 & 7740 & h1 & 6440 & $c-g$ & 17 & 8940 & $a-d$ & 6580 & $a-c$ & 26 & 8340 & $f-1$ & 6510 & $b-g$ & 22 \\
\hline $\mathrm{G} 23$ & 8940 & $\mathrm{~b}$ & 6940 & $\mathrm{bc}$ & 22 & 8570 & $c-g$ & 5930 & $\mathrm{f}-\mathrm{k}$ & 31 & 8750 & $a-e$ & 6430 & $c-g$ & 26 \\
\hline G24 & 8320 & $c-f$ & 5850 & gh & 30 & 8690 & b-g & 5830 & $\mathrm{~g}-1$ & 33 & 8500 & $\mathrm{~d}-1$ & 5840 & 1 & 31 \\
\hline Ceyhan-99 & 8070 & e-h & 6560 & c-f & 19 & 8740 & $b-f$ & 6560 & a-d & 25 & 8410 & $\mathrm{e}-1$ & 6560 & $a-f$ & 22 \\
\hline Average & 8340 & $\mathrm{a}$ & 6590 & $\mathrm{~b}$ & 21 & 8700 & $\mathrm{a}$ & 6020 & $\mathrm{~b}$ & 31 & 8520 & $\mathrm{a}$ & 6080 & $\mathrm{~b}$ & 26 \\
\hline Lsd(0.05) & $51.9 * *$ & & 69.8 ** & & & $49.3 * *$ & & $51.5^{* *}$ & & & $12.7 * *$ & & $37.3 * *$ & & \\
\hline
\end{tabular}

Letters in the same column from top to bottom are statistically different at the level of $p<0.01$ or $p<0.05$. IC1: Irrigated conditions in the first season, IC2: Irrigated conditions in the second season, RC1: Rainfed conditions in the first season, RC2: Rainfed conditions in the second season, IC: Irrigated conditions, RC: Rainfed conditions, **: Statistically significant at $0.01, *$ : Statistically significant at 0.05 
Table 5. The results of the combined analysis of both growing seasons for the investigated parameters and the groups formed

\begin{tabular}{|c|c|c|c|c|c|c|c|c|c|c|c|c|}
\hline & IC & & RC & & IC & & $\mathrm{RC}$ & & IC & & RC & \\
\hline & GY & & GY & & HW & & HW & & TGW & & TGW & \\
\hline G1 & 8480 & $\mathrm{~d}-1$ & 6770 & $a-c$ & 82.7 & $\mathrm{jk}$ & 79.8 & $a-g$ & 37.4 & e-h & 31.3 & b-g \\
\hline G2 & 8190 & $h-j$ & 6300 & d-h & 83.2 & $g-j$ & 78.6 & $e-j$ & 35.9 & $\mathrm{~h}-\mathrm{k}$ & 28.6 & $g-j$ \\
\hline G3 & 8910 & $\mathrm{ab}$ & 6440 & $c-g$ & 83.7 & e-g & 80.8 & $a-d$ & 39.9 & $\mathrm{bc}$ & 34.2 & $\mathrm{a}$ \\
\hline G4 & 8860 & $a-c$ & 6110 & $g-1$ & 83.3 & $f-1$ & 79.4 & b-h & 35.8 & h-1 & 30.2 & d-g \\
\hline Dinç & 8550 & $c-g$ & 6560 & $a-f$ & 83.8 & $d-f$ & 79.7 & $a-g$ & 34.0 & 1 & 27.0 & $1-k$ \\
\hline G6 & 8500 & $\mathrm{~d}-1$ & 6930 & $a b$ & 84.4 & $a-d$ & 81.1 & $a-c$ & 39.8 & $\mathrm{bc}$ & 31.2 & c-g \\
\hline G7 & 8590 & $b-f$ & 6100 & $g-1$ & 81.9 & 1 & 74.7 & 1 & 36.8 & $f-1$ & 26.2 & $\mathrm{jk}$ \\
\hline G8 & 7880 & $\mathrm{j}$ & 6480 & $c-g$ & 84.5 & $a-c$ & 81.4 & $a b$ & 40.7 & $\mathrm{~b}$ & 33.2 & $a-c$ \\
\hline G9 & 8210 & $g-j$ & 5890 & $h_{1}$ & 83.4 & $e-1$ & 78.3 & g-k & 37.1 & e-h & 28.8 & $f-j$ \\
\hline Pehlivan & 7930 & $\mathrm{j}$ & 5830 & 1 & 82.8 & $\mathrm{jk}$ & 79.0 & $c-1$ & 42.9 & $\mathrm{a}$ & 34.1 & $a b$ \\
\hline G11 & 8640 & $b-f$ & 6220 & $e-1$ & 83.6 & $e-h$ & 78.6 & $e-j$ & 34.5 & $j-1$ & 26.4 & $1-\mathrm{k}$ \\
\hline G12 & 9050 & $\mathrm{a}$ & 6660 & $a-d$ & 82.7 & $\mathrm{jk}$ & 78.4 & $f-k$ & 36.3 & $f-j$ & 29.0 & $f-j$ \\
\hline G13 & 8180 & $1 \mathrm{j}$ & 5830 & 1 & 81.3 & $\mathrm{mn}$ & 76.6 & $j-1$ & 37.8 & d-g & 30.2 & d-g \\
\hline G14 & 8650 & $b-f$ & 6610 & $a-e$ & 83.1 & h-k & 78.9 & $d-1$ & 36.7 & $f-1$ & 28.9 & $f-j$ \\
\hline Aday-12 & 8540 & $c-h$ & 6110 & $g-1$ & 81.5 & $1-n$ & 76.4 & $\mathrm{kl}$ & 42.7 & $\mathrm{a}$ & 32.0 & a-e \\
\hline G16 & 9010 & $\mathrm{a}$ & 6450 & $c-g$ & 83.9 & c-e & 80.7 & a-e & 39.9 & $\mathrm{bc}$ & 32.9 & $a-d$ \\
\hline G17 & 8800 & $a-d$ & 6140 & $f-1$ & 83.4 & $f-1$ & 77.5 & h-k & 36.1 & $g-j$ & 26.3 & $1-\mathrm{k}$ \\
\hline G18 & 8410 & $e-1$ & 5860 & 1 & 84.6 & $a b$ & 80.5 & $a-f$ & 39.5 & b-d & 31.6 & $a-f$ \\
\hline G19 & 8480 & $\mathrm{~d}-1$ & 5820 & 1 & 84.3 & $b-d$ & 80.2 & $a-g$ & 34.2 & $\mathrm{kl}$ & 27.3 & $h-j$ \\
\hline Tekin & 8300 & $f-1$ & 6230 & $\mathrm{~d}-1$ & 84.8 & $\mathrm{a}$ & 81.7 & $\mathrm{a}$ & 37.2 & $e-h$ & 30.1 & d-h \\
\hline G21 & 8770 & $a-d$ & 6950 & $\mathrm{a}$ & 81.0 & $\mathrm{n}$ & 77.1 & $1-\mathrm{k}$ & 36.3 & $f-j$ & 29.1 & $f-1$ \\
\hline G22 & 8340 & $f-1$ & 6510 & b-g & 82.9 & $1-k$ & 80.7 & a-e & 38.1 & $c-f$ & 32.1 & a-e \\
\hline G23 & 8750 & a-e & 6430 & $c-g$ & 81.7 & $1 \mathrm{~m}$ & 77.6 & h-k & 38.8 & b-e & 30.5 & $c-g$ \\
\hline G24 & 8500 & $\mathrm{~d}-1$ & 5840 & 1 & 80.2 & o & 74.7 & 1 & 35.0 & $1-1$ & 24.4 & $\mathrm{k}$ \\
\hline Ceyhan-99 & 8410 & e-1 & 6560 & $a-f$ & 82.6 & $\mathrm{k}$ & 79.6 & $a-h$ & 36.0 & $\mathrm{~g}-\mathrm{k}$ & 29.2 & $e-j$ \\
\hline Average & 8520 & & 6310 & & 83.0 & & 79 & & 37.6 & & 29.8 & \\
\hline Lsd(0.05) & $35.5^{* *}$ & & $43.0^{* *}$ & & $0.6^{* *}$ & & $2.1 * *$ & & $1.9^{* *}$ & & $2.9^{* * *}$ & \\
\hline
\end{tabular}




\begin{tabular}{|c|c|c|c|c|c|c|c|c|c|c|c|}
\hline & IC & & $\mathbf{R C}$ & IC & & RC & & IC & & $\mathrm{RC}$ & \\
\hline & PR & & PR & ZS & & $\mathbf{Z S}$ & & SPSM & & SPSM & \\
\hline G1 & 13.2 & b-e & 14.0 & 38.0 & $a b$ & 42.3 & $b-f$ & 104.3 & $c-e$ & 91.3 & $\mathrm{j}$ \\
\hline G2 & 12.6 & d-g & 14.7 & 31.5 & $g-1$ & 43.5 & a-e & 113.8 & b-e & 111.0 & $b-f$ \\
\hline G3 & 12.8 & $c-g$ & 13.3 & 32.8 & e-h & 39.0 & e-g & 103.8 & c-e & 99.0 & $g-j$ \\
\hline G4 & 12.5 & e-g & 14.2 & 30.5 & $\mathrm{~h}_{1}$ & 40.0 & d-g & 104.8 & $c-e$ & 93.5 & $1 \mathrm{j}$ \\
\hline Dinç & 12.8 & $c-g$ & 14.2 & 29.8 & $1 \mathrm{j}$ & 38.0 & fg & 103.8 & $c-e$ & 101.3 & $e-j$ \\
\hline G6 & 13.2 & $b-f$ & 14.4 & 39.3 & $\mathrm{a}$ & 47.5 & $\mathrm{a}$ & 111.5 & b-e & 112.5 & a-e \\
\hline G7 & 13.1 & $b-f$ & 15.2 & 35.8 & $b-d$ & 46.0 & $a-c$ & 110.8 & b-e & 105.8 & $c-h$ \\
\hline G8 & 12.8 & $c-g$ & 13.7 & 34.8 & $d-f$ & 42.3 & $b-f$ & 101.5 & de & 105.3 & $\mathrm{c}-1$ \\
\hline G9 & 12.9 & b-g & 14.8 & 32.8 & e-h & 45.0 & $a-d$ & 112.0 & b-e & 124.3 & a \\
\hline Pehlivan & 13.4 & $a-d$ & 15.4 & 32.3 & $f-1$ & 40.0 & d-g & 97.0 & $\mathrm{e}$ & 113.3 & a-d \\
\hline G11 & 12.4 & $\mathrm{fg}$ & 14.4 & 32.3 & $f-1$ & 42.8 & $a-f$ & 112.8 & b-e & 119.3 & $a b$ \\
\hline G12 & 13.1 & $b-f$ & 15.2 & 30.3 & $h-j$ & 44.5 & $a-d$ & 102.3 & c-e & 109.8 & b-g \\
\hline G13 & 14.2 & $\mathrm{a}$ & 15.7 & 36.5 & b-d & 40.3 & d-g & 119.8 & $a-c$ & 101.5 & $d-j$ \\
\hline G14 & 12.1 & $\mathrm{~g}$ & 13.8 & 24.5 & 1 & 36.5 & $\mathrm{~g}$ & 107.0 & $c-e$ & 102.3 & $d-j$ \\
\hline Aday-12 & 12.9 & $c-g$ & 14.0 & 29.8 & $1 \mathrm{j}$ & 40.3 & d-g & 103.3 & c-e & 103.3 & $d-1$ \\
\hline G16 & 13.1 & $b-f$ & 14.2 & 30.0 & $1 \mathrm{j}$ & 42.3 & $b-f$ & 113.0 & b-e & 108.5 & b-h \\
\hline G17 & 13.6 & $a-c$ & 15.1 & 39.8 & $\mathrm{a}$ & 45.5 & $a-c$ & 116.0 & b-d & 97.0 & $h-j$ \\
\hline G18 & 13.2 & $b-f$ & 14.1 & 31.8 & $\mathrm{~g}-1$ & 36.8 & $\mathrm{~g}$ & 107.8 & $c-e$ & 91.0 & $\mathrm{j}$ \\
\hline G19 & 13.3 & $a-e$ & 14.7 & 35.3 & c-e & 45.0 & $a-d$ & 116.5 & b-d & 105.8 & $\mathrm{c}-\mathrm{h}$ \\
\hline Tekin & 13.4 & $a-e$ & 14.7 & 34.5 & $d-f$ & 44.5 & $a-d$ & 108.0 & c-e & 99.5 & $f-j$ \\
\hline G21 & 13.8 & $\mathrm{ab}$ & 14.2 & 34.0 & d-g & 41.5 & $c-g$ & 131.8 & a & 120.3 & $a b$ \\
\hline G22 & 13.5 & $a-c$ & 14.8 & 27.8 & $\mathrm{jk}$ & 38.8 & e-g & 119.8 & $\mathrm{bc}$ & 108.5 & b-h \\
\hline G23 & 13.2 & $b-f$ & 14.8 & 38.0 & $a b$ & 46.8 & $a b$ & 98.3 & $\mathrm{e}$ & 109.3 & b-g \\
\hline G24 & 13.0 & $b-g$ & 15.4 & 26.3 & $\mathrm{kl}$ & 39.3 & e-g & 127.8 & $a b$ & 115.3 & $a-c$ \\
\hline Ceyhan-99 & 13.0 & $b-f$ & 14.0 & 37.8 & $a-c$ & 45.3 & $\mathrm{a}-\mathrm{d}$ & 112.8 & b-e & 111.4 & a-g \\
\hline Average & 13.1 & & 14.5 & 33.0 & & 42.1 & & 110.4 & & 106.4 & \\
\hline $\operatorname{Lsd}(0.05)$ & $0.9^{*}$ & & Ö.D. & $2.7 * *$ & & $5.2 * *$ & & $17.6^{*}$ & & $11.9 * *$ & \\
\hline
\end{tabular}

APPLIED ECOLOGY AND ENVIRONMENTAL RESEARCH 17(1):1431-1450.

http://www.aloki.hu • ISSN 15891623 (Print) • ISSN 17850037 (Online)

DOI: http://dx.doi.org/10.15666/aeer/1701_14311450

(c) 2019, ALÖKI Kft., Budapest, Hungary 
Karaman: Evaluation of bread wheat genotypes in irrigated and rainfed conditions using biplot analysis

$$
-1444 \text { - }
$$

\begin{tabular}{|c|c|c|c|c|c|c|c|c|c|c|c|}
\hline & IC & & $\mathbf{R C}$ & & IC & & $\mathbf{R C}$ & & IC & $\mathbf{R C}$ & \\
\hline & SL & & SL & & FSPS & & FSPS & & GPS & GPS & \\
\hline G1 & 9.1 & e-g & 9.5 & g-1 & 17.8 & $d-f$ & 17.7 & $\mathrm{~cd}$ & 55.5 & 55.3 & bc \\
\hline G2 & 8.7 & $\mathrm{~g}$ & 9.9 & $e-1$ & 19.0 & $b-d$ & 19.5 & $a b$ & 49.5 & 56.9 & $\mathrm{a}-\mathrm{c}$ \\
\hline G3 & 10.0 & $a-e$ & 11.6 & $\mathrm{a}-\mathrm{c}$ & 18.0 & $c-f$ & 18.9 & $a-c$ & 54.4 & 56.8 & $a-c$ \\
\hline G4 & 10.8 & $\mathrm{ab}$ & 10.5 & d-g & 18.7 & b-e & 20.0 & $\mathrm{a}$ & 49.3 & 51.4 & $\mathrm{c}$ \\
\hline Dinç & 9.1 & e-g & 9.3 & h1 & 18.9 & b-d & 19.0 & $a-c$ & 55.9 & 48.3 & $\mathrm{~cd}$ \\
\hline G6 & 10.9 & $\mathrm{a}$ & 11.7 & $a b$ & 20.0 & $a b$ & 20.1 & $\mathrm{a}$ & 52.1 & 55.2 & $\mathrm{bc}$ \\
\hline G7 & 9.6 & $\mathrm{c}-\mathrm{g}$ & 10.6 & $c-f$ & 18.1 & $c-f$ & 17.9 & b-d & 56.2 & 53.6 & $\mathrm{c}$ \\
\hline G8 & 10.3 & $a-c$ & 10.7 & b-e & 19.4 & $a-c$ & 20.5 & $\mathrm{a}$ & 47.7 & 49.7 & $\mathrm{~cd}$ \\
\hline G9 & 10.4 & $a-c$ & 11.9 & $\mathrm{a}$ & 18.6 & $b-f$ & 19.7 & $\mathrm{a}$ & 53.3 & 66.3 & $\mathrm{a}$ \\
\hline Pehlivan & 10.0 & $a-e$ & 10.4 & d-h & 20.6 & $\mathrm{a}$ & 20.6 & $\mathrm{a}$ & 39.0 & 40.1 & $\mathrm{~d}$ \\
\hline G11 & 9.2 & d-g & 9.3 & h1 & 19.5 & $a-c$ & 20.3 & $\mathrm{a}$ & 55.7 & 65.3 & $a b$ \\
\hline G12 & 9.7 & b-g & 10.6 & $\mathrm{c}-\mathrm{g}$ & 17.3 & ef & 19.4 & $\mathrm{ab}$ & 47.1 & 55.1 & $\mathrm{bc}$ \\
\hline G13 & 10.0 & a-e & 10.8 & a-e & 19.0 & $b-d$ & 19.8 & $\mathrm{a}$ & 47.4 & 50.1 & $\mathrm{~cd}$ \\
\hline G14 & 10.3 & $a-c$ & 10.4 & d-g & 18.7 & b-e & 20.6 & $\mathrm{a}$ & 46.7 & 51.1 & $\mathrm{c}$ \\
\hline Aday-12 & 10.4 & $a-c$ & 9.5 & $\mathrm{~g}-1$ & 19.9 & $a b$ & 19.5 & $a b$ & 55.2 & 51.9 & $\mathrm{c}$ \\
\hline G16 & 10.4 & $a-c$ & 11.2 & $a-d$ & 18.7 & b-e & 19.7 & $\mathrm{a}$ & 53.0 & 56.0 & $a-c$ \\
\hline G17 & 10.3 & $a-c$ & 9.8 & $e-1$ & 19.2 & $a-d$ & 19.7 & $\mathrm{a}$ & 60.2 & 58.5 & $a-c$ \\
\hline G18 & 10.7 & $a b$ & 11.1 & $a-d$ & 18.9 & b-d & 18.9 & $a-c$ & 53.7 & 50.7 & $\mathrm{c}$ \\
\hline G19 & 8.9 & fg & 8.9 & 1 & 17.2 & f & 16.9 & $\mathrm{~d}$ & 53.5 & 50.4 & $c-d$ \\
\hline Tekin & 10.2 & $a-d$ & 11.1 & $a-d$ & 18.8 & b-d & 19.1 & $a-c$ & 50.1 & 55.1 & $\mathrm{bc}$ \\
\hline G21 & 9.6 & $c-g$ & 9.6 & $f-1$ & 18.2 & $c-f$ & 17.6 & $\mathrm{~cd}$ & 52.9 & 51.0 & $\mathrm{c}$ \\
\hline G22 & 10.0 & $a-e$ & 11.3 & $a-d$ & 19.1 & $a-d$ & 19.1 & $a-c$ & 53.5 & 49.8 & $\mathrm{~cd}$ \\
\hline G23 & 9.9 & $a-f$ & 11.4 & $a-d$ & 18.9 & b-d & 20.0 & a & 56.3 & 58.7 & $a-c$ \\
\hline G24 & 10.3 & $a-c$ & 10.0 & e-h & 20.0 & $\mathrm{ab}$ & 19.5 & $a b$ & 55.4 & 54.2 & $\mathrm{c}$ \\
\hline Ceyhan-99 & 9.4 & $\mathrm{c}-\mathrm{g}$ & 9.4 & $f-1$ & 18.9 & b-d & 19.2 & $\mathrm{a}-\mathrm{c}$ & 48.4 & 47.2 & $\mathrm{c}-\mathrm{d}$ \\
\hline Average & 9.9 & & 10.4 & & 18.8 & & 19.3 & & 52.1 & 53.5 & \\
\hline Lsd(0.05) & $1.1 * *$ & & $1.1^{* *}$ & & $1.3^{* *}$ & & $1.7 * *$ & & Ö.D & $10.6^{*}$ & \\
\hline
\end{tabular}

APPLIED ECOLOGY AND ENVIRONMENTAL RESEARCH 17(1):1431-1450.

http://www.aloki.hu • ISSN 15891623 (Print) • ISSN 17850037 (Online)

DOI: http://dx.doi.org/10.15666/aeer/1701_14311450

(๐) 2019, ALÖKI Kft., Budapest, Hungary 


\section{Evaluation of genotypes in terms of drought tolerance}

Table 6 presents the drought tolerance parameters of the genotypes based on the average values over the two growing seasons.

Table 6. Two year averages of drought tolerance parameters

\begin{tabular}{|c|c|c|c|c|c|c|c|c|c|c|}
\hline & Yp & Ys & TOL & STI & GMP & MP & HM & YSI & YI & DRI \\
\hline G1 & 8480 & 6770 & 1710 & 0.79 & 757.9 & 763 & 753 & 0.80 & 1.07 & 0.86 \\
\hline $\mathrm{G} 2$ & 8190 & 6300 & 1890 & 0.71 & 718.6 & 725 & 712 & 0.77 & 1.00 & 0.77 \\
\hline G3 & 8910 & 6440 & 2480 & 0.79 & 757.5 & 768 & 748 & 0.72 & 1.02 & 0.74 \\
\hline G4 & 8860 & 6110 & 2750 & 0.75 & 735.9 & 749 & 723 & 0.69 & 0.97 & 0.67 \\
\hline Dinç & 8550 & 6560 & 1990 & 0.77 & 748.8 & 755 & 742 & 0.77 & 1.04 & 0.80 \\
\hline G6 & 8500 & 6930 & 1570 & 0.81 & 767.2 & 771 & 763 & 0.82 & 1.10 & 0.90 \\
\hline G7 & 8590 & 6100 & 2490 & 0.72 & 723.9 & 735 & 713 & 0.71 & 0.97 & 0.69 \\
\hline G8 & 7880 & 6480 & 1400 & 0.70 & 714.3 & 718 & 711 & 0.82 & 1.03 & 0.84 \\
\hline G9 & 8210 & 5890 & 2320 & 0.67 & 695.7 & 705 & 686 & 0.72 & 0.93 & 0.67 \\
\hline Pehlivan & 7930 & 5830 & 2100 & 0.64 & 680.2 & 688 & 672 & 0.73 & 0.92 & 0.68 \\
\hline G11 & 8640 & 6220 & 2420 & 0.74 & 732.9 & 743 & 723 & 0.72 & 0.99 & 0.71 \\
\hline G12 & 9050 & 6660 & 2390 & 0.83 & 776.3 & 785 & 767 & 0.74 & 1.06 & 0.78 \\
\hline G13 & 8180 & 5830 & 2350 & 0.66 & 690.8 & 701 & 681 & 0.71 & 0.92 & 0.66 \\
\hline G14 & 8650 & 6610 & 2040 & 0.79 & 756.4 & 763 & 750 & 0.76 & 1.05 & 0.80 \\
\hline Aday-12 & 8540 & 6110 & 2430 & 0.72 & 722.3 & 732 & 712 & 0.72 & 0.97 & 0.69 \\
\hline G16 & 9010 & 6450 & 2560 & 0.80 & 762.6 & 773 & 752 & 0.72 & 1.02 & 0.73 \\
\hline G17 & 8800 & 6140 & 2660 & 0.75 & 735.4 & 747 & 724 & 0.70 & 0.97 & 0.68 \\
\hline G18 & 8410 & 5860 & 2550 & 0.68 & 701.8 & 713 & 690 & 0.70 & 0.93 & 0.65 \\
\hline G19 & 8480 & 5820 & 2660 & 0.68 & 702.8 & 715 & 691 & 0.69 & 0.92 & 0.63 \\
\hline Tekin & 8300 & 6230 & 2070 & 0.71 & 719.3 & 727 & 712 & 0.75 & 0.99 & 0.74 \\
\hline G21 & 8770 & 6950 & 1820 & 0.84 & 780.5 & 786 & 775 & 0.79 & 1.10 & 0.87 \\
\hline G22 & 8340 & 6510 & 1830 & 0.75 & 737.0 & 743 & 731 & 0.78 & 1.03 & 0.81 \\
\hline $\mathrm{G} 23$ & 8750 & 6430 & 2320 & 0.78 & 750.6 & 759 & 742 & 0.74 & 1.02 & 0.75 \\
\hline G24 & 8500 & 5840 & 2660 & 0.68 & 704.7 & 717 & 692 & 0.69 & 0.93 & 0.64 \\
\hline Ceyhan-99 & 8410 & 6560 & 1850 & 0.76 & 742.7 & 748 & 737 & 0.78 & 1.04 & 0.81 \\
\hline Average & 8520 & 6310 & 2210 & 0.74 & 732.7 & 741 & 724 & 0.74 & 1.0 & 0.74 \\
\hline
\end{tabular}

Yp: Grain yield in irrigated conditions, Ys: Grain yield in rainfed conditions, TOL: Tolerance, STI: Stress tolerance index, GMP: Geometric mean productivity (GMP), MP: Mean productivity, HM: Harmonic mean, YSI: Yield stability index, YI: Yield index, DRI: Drought resistance index.

Table 6 shows the results of drought tolerant parameters obtained by grain yield formulas under irrigated and rainfed conditions with the highest grain yield being obtained from G12 (9050 kg ha-1) and G21 (6950 kg ha $\left.{ }^{-1}\right)$, respectively. The tolerance index (TOL) indicates the yield differences between the best and worst conditions for genotypes. The lowest TOL was found in G8 and the highest in G4. G8 with the lowest TOL had higher grain yield than the experimental average for rainfed conditions but did not have better grain yield potential in irrigated conditions compared to other genotypes. Therefore, it can be stated that the performance of some genotypes does not greatly vary in favorable or poor environmental conditions. G4 can be considered as the genotype with the most favorable response to irrigation.

In addition, G17, G19 and G24 with high TOL values were identified as genotypes that had a positive response to irrigation, which significantly increased their yield potential. Although their TOL value was high, G3, G12 and G16 had high grain yields 
both rainfed and irrigated conditions. This shows that these genotypes well adapted to both environments. Many researchers have reported that high values of STI, GMP, MP, HM and YI are indicative of the increased drought tolerance of genotypes (Fernandez, 1992; Ramirez and Kelly, 1998; Akçura et al., 2011; Aktaş, 2017).

In the current study, the highest values for these parameters were obtained from G6, G12, G16 and G21, suggesting that these genotypes had good grain yields under both irrigated and rainfed conditions. The remaining two drought parameters investigated in the study were YSI and DRI, which, at low levels, have been shown to indicate drought tolerance (Lan, 1998; Bouslama and Schapaugh, 1984). In the current study, the lowest YSI values belonged to G4 (0.69), G17 (0.70), G18 (0.70), G19 (0.69) and G24 (0.69) and the lowest DRI values were observed in G18 (0.65), G19 (0.63) and G24 (0.64). Anwar et al. (2011) and Aktaş (2017) reported that YI is associated with average yield in conditions presenting with water stress and can therefore be used in drought resistance studies. G6 and G21 were more prominent in terms of YI.

According to the biplot graph demonstrating the status of genotypes in terms of drought parameters and the relationship between these parameters (Figure 6); there was a significant positive relationship between; MP, STI, GMP and HM; YI and grain yield in irrigated conditions; DRI and YI and grain yield in rainfed conditions; and DRI and YSI. The best performing genotypes were found to be G12 and G16 for grain yield in irrigated conditions; G12 and G21 for MP, STI, GMP and HM; G21 for YI and grain yield in rainfed conditions; G6 for DRI and YSI; and G4, G19 and G24 for TOL. Furthermore, the MP, STI, GMP and HM parameters were found to be associated with grain yield in irrigated and rainfed conditions. Whereas YI, DRI and YSI were correlated with grain yield in rainfed conditions.

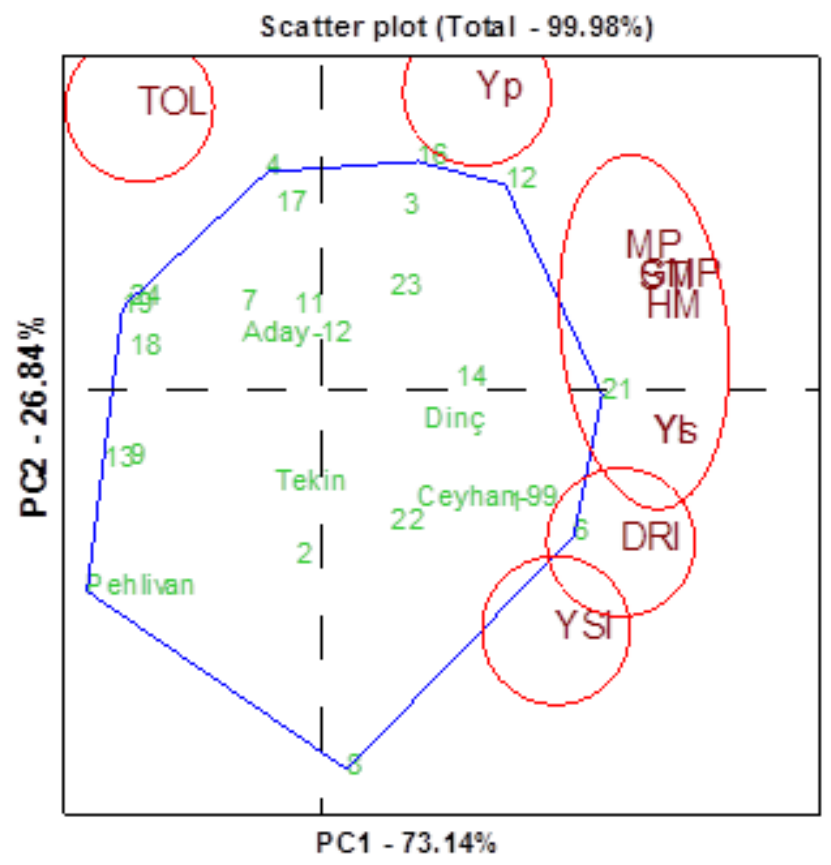

Figure 6. GGE-biplot of the correlation between genotypes and drought tolerance parameters 


\section{Conclusion}

The results of ANOVA and GGE-biplot analyses of the experiments conducted in two growing seasons under different environmental conditions revealed that the prominent genotypes were G1, Dinç, G6, G12, G14, G21 and Ceyhan-99 for the rainfed conditions and G3, G4, G12, G16, G17, G21 and G23 genotypes for the irrigated conditions. G12 and G21 lines produced favorable results under both rainfed and irrigated conditions, which suggests that these lines better adapt to different climatic conditions than other genotypes. In addition, particularly in rainfed conditions, the G3 line performed better in both yield components (FSPS and SL) and technological quality parameters (TGW and HW). This line (G3) can be used as a parent in breeding studies. Concerning drought parameters, there was a significant positive relationship between MP, STI, GMP and HM, and a significant negative correlation between TOL and YSI. It was also determined that MP, STI, GMP and HM parameters can be used in the selection of genotypes suitable for irrigated and rainfed conditions and YI, DRI and YSI can assist in choosing the best genotypes for rainfed conditions presenting with water stress.

Based on the results of the study, we conclude that G6, G12, G16 and G21 are promising candidate lines for registration.

\section{REFERENCES}

[1] Akçura, M., Partigoç, F., Kaya, Y. (2011): Evaluating of drought stress tolerance based on selection indices in Turkish bread wheat landraces. - The Journal of Animal \& Plant Sciences 21(4): 700-709.

[2] Aktas, H. (2017): Türkiye'de yoğun ekim alanına sahip bazı arpa (hordeum vulgare 1.) çeşitlerinin destek sulamalı ve yağışa dayalı koşullarda değerlendirilmesi. - Tekirdağ Ziraat Fakültesi Dergisi 14(03): 86-97.

[3] Anonim (2017): Diyarbakır Meteoroloji Bölge Müdürlüğü Kayıtları. Https://www.mgm.gov.tr/Veri değerlendirme/İl-ve-İlceler-İstatistik.Aspx?=Diyarbakır.

[4] Anonymous (1990): Approved Methods of the American Association of Cereal Chemists. - American Association of Cereal Chemists, Approved Methods Committee, USA.

[5] Anwar, J., Ghulam, M. S., Makhdoom, H., Javed, A., Mujahid, H., Munir, M. (2011): Drought tolerance indices and their correlation with yield in exotic wheat genotypes. Pakistan Journal Botany 43(3): 1527-1530.

[6] Atlı, A., Koçak, N., Aktan, M. (1993): Ülkemiz çevre koşullarının kaliteli makarnalık buğday yetiştirmeye uygunluk yönünden değerlendirilmesi. - Orta Anadolu'da Hububat Tarımının Sorunları ve Çözüm Yolları Sempozyumu, Konya: 345-351.

[7] Aydoğan, S., Soylu, S. (2017): Ekmeklik buğday çeşitlerinin verim ve verim öğeleri ile bazı kalite özelliklerinin belirlenmesi. - Tarla Bitkileri Merkez Araştırma Enstitüsü Dergisi 26(1): 24-30.

[8] Blum, A. (1998): Plant Breeding for Stress Environments. - CRC Press, Boca Raton, Florida.

[9] Bohac, J., Cermin, L. (1969): A Study of The Correlation Between Factors Determining The Productivity of Wheat Ears. - Plant Breed. Abs. 39(1): 58.

[10] Bouslama, M., Schapaugh, W. T. (1984): Stress tolerance in soybean. Evaluation of three screening techniques for heat and drought tolerance. - Crop Science 24: 933-937.

[11] Chakherchaman, S. A., Mostafaei, H., Imanparastand, L., Eivazian, M. R. (2009): Evaluation of drought tolerance in lentil advanced genotypes in Ardabil region. - Iran J. Food Agriculture Environment 7(3-4): 283-288. 
[12] Chamurliyski, P., Atanasova, D., Penchev, E. (2015): Productivity of foreign common winter wheat cultivars (Triticum aestivum L.) under the conditions of dobrudzha region. Agriculture \& Forestry, Podgorica 61(1): 77-83.

[13] Çetin, Ö., Uygan, D., Boyac1, H., Öğretir, K. (1999): Kışlık buğdayda sulama-azot ve bazı önemli iklim özellikleri arasındaki ilişkiler. - Türkiye III. Tarla Bitkileri Kongresi, Cilt I, 151-156, Adana.

[14] Dhanda, S. S., Sethi, G. S., Behl, R. K. (2004): Indices of drought tolerance in wheat genotypes at early stages of plant growth. - J. Agronomy \& Crop Science 190: 6-12.

[15] Doğan, Y., Kendal, E. (2013): Diyarbakır koşullarında bazı ekmeklik buğday (Triticum Aestivum L.) genotiplerinin tane verimi ve bazı kalite özelliklerinin belirlenmesi. - YYÜ Tarım Bilimleri Dergisi 23(3): 199-208.

[16] Doğan, Y., Kendal, E., Oral, E. (2016): Identifying of relationship between traits and grain yield in spring Barley by GGE biplot analysis. - Agriculture and Forestry 6(24): 239-252.

[17] Erekul, O., Köhn, W. (2006): Effect of weather and soil conditions on yield components and bread-making quality of winter wheat (Triticum aestivum L.) and winter triticale (Triticosecale Wittm.) varieties in North-East Germany. - J. Agronomy and Crop Science 192: 452-464.

[18] Erkul, E. (2006): Sulamalı koşullarda ileri ekmeklik buğday hatlarının tane verimi ve bazı kalite özelliklerinin belirlenmesi. - ADÜ Ziraat Fakültesi Dergisi 3(1): 27-32.

[19] FAO. (2015): Food Agriculture Organization. - http://www.fao.org/index_en.htm.

[20] Farshadfar, E., Jamshid, B., Aghaee, M. (2012): Biplot analysis of drought tolerance indicators in bread wheat lanraces of Iran. - International Journal of Agriculture and Crop Sciences. IJACS/2012/4-5/226-233.

[21] Fernandez, G. C. J. (1992): Effective selection criteria for assessing plant stress tolerance. - Proceedings of The İnternational Symposium on Adaptation of Vegetable And Other Food Crops in Temperature and Water Stress, Taiwan: 257-270.

[22] Gavuzzi, P., Rizza, F., Palumbo, M., Campaline, R. G., Ricciardiand, G. L., Borghi, B. (1997): Evaluation of field and laboratory predictors of drought and heat tolerance in winter cereals. - Plant Science 77: 523-531.

[23] Gebeyehou, G., Knott, D. R., Baker, R. J. (1982): Relations among durations of vegetative and grain filling phases, yield components and grain yield in durum wheat cultivars. - CropSci 22: 287-290.

[24] Genç, İ. (1974): Yerli ve Yabancı Ekmeklik ve Makarnalık Buğday Çeşitlerinde Verim ve Verime Etkili Başlıca Karakterler Üzerinde Araştırmalar. - Çukurova Üniversitesi Ziraat Fakültesi Yayınları, Yayın No: 82. Adana.

[25] GENSTAT. (2009): GenStat for Windows (12th Edition) Introduction. - VSN International, Hemel Hempstead.

[26] Gomez, K., Gomez, A. A. (1984): Statistical Procedures for Agricultural Research. - 2nd Edition. John Wiley and Sons. New York. 680 pp.

[27] Hossain, A. B. S., Sears, A. G., Coxand, T. S., Paulsen, G. M. (1990): Desiccation tolerance and its relationship to assimilate partitioning in winter wheat. - CropScience 30: 622-627.

[28] Karaman, M. (2013): Investigation of some physiological and morphological parameters in some bread wheat (triticum aestivum 1.) varieties. - Master Thesis, Dicle University.

[29] Karaman, M. (2017): Determination of physiological and morphological parameters associated with grain yield and quality traits in durum wheat. - Ph.D. Thesis, Dicle University.

[30] Kendal, E. (2015): Relationship between chlorophyll and other features in durum wheat (Triticum turgidum L. var. durum) using SPAD and biplot analyses. - Journal of Agricultural Science and Technology 17: 1873-1886. 
[31] K1lıc, H., Akar, T., Kendal, E., Sayım, I. (2010): Evaluation of grain yield and quality of barley varieties under rainfed conditions. - African Journal of Biotechnology 9(46): 7825-7830.

[32] Kılıç, H., Kendal, E., Aktaş, H. (2018): Evaluation of yield and some quality characters of winter barley (hordeum vulgare 1.) genotypes using biplot analysis. - Agriculture \& Forestry 64(3): 101-111. Podgorica.DOI: 10.17707/Agricultural Forest.64.3.09.

[33] Kızılgeçi, F., Yıldırım, M., Akıncı, C., Albayrak, Ö. (2016): Bazı arpa genotiplerinin Diyarbakır ve Mardin koşullarında verim ve kalite parametrelerinin incelenmesi. - Iğdır Üniversitesi Fen Bilimleri Enstitüsü. Dergisi 6(3): 161-169.

[34] Knott, D. R., Talukdar, B. (1971): Increasing seed weight wheat yield and it's effects on yield components and quality. - Crop Sci. 11(2): 280-283.

[35] Lan, J. (1998): Comparison of Evaluating Methods for Agronomic Drought resistance in Crops. - Acta Agricultural Boreali-Occidentalis Sinica 7: 85-87.

[36] Mohammadi, M., Karimizadeh, R., Abdipour, M. (2011): Evaluation of drought tolerance in bread wheat genotypes under dryland and supplemental irrigation conditions. Australian Journal of Crop Sciences 5(4): 487-493.

[37] Nazar, H., Erekul, E., Koca, Y. O. (2012): Ekmeklik buğday çeşitlerinin tane verimi ve kalitesi üzerine farklı yaprak gübresi uygulamalarının etkisi. - Adnan Menderes Üniversitesi Ziraat Fakültesi Dergisi 9(2): 5-12.

[38] Nouri, A., Etminan, A., Teixeira da Silva, J. A., Mohammadi, R. (2011): Assessment of yield, yield-related traits and drought tolerance of durum wheat genotypes (Triticum turjidum var. durum Desf.). - Aust. J. Crop Sci. 5(1): 8-16.

[39] Oral, E. (2018): Effect of nitrogen fertilization levels on grain yield and yield components in triticale based on AMMI and GGE biplot analysis. - Applied Ecology And Environmental Research 16(4): 4865-4878.

[40] Öztürk, A., Akten, G. (1999): Some morpho-physiological characters in winter wheat and their effects on grain yield. - Tr. J. of Agriculture and Forestry 23 (Ek say1 2): 409-422.

[41] Öztürk, A., Aydin, F. (2004): Effect of water stress at various growth stages on some quality characteristics of winter wheat. - Journal of Agronomy and Crop Science 190(2): 93-99.

[42] Öztürk, İ., Korkut, K. Z. (2018): Ekmeklik buğday (TriticumaestivumL)'ın farklı gelişme dönemlerinde kuraklığın verim ve verim unsurlarına etkisi. - Tekirdağ Ziraat Fakültesi Dergisi 15(2): 128-137.

[43] Peterson, C. J., Graybosch, R. A., Baenziger, P. S., Grombacher, A. W. (1992): Genotype and environment effects on quality characteristics of hard red winter wheat. - Crop Sci. 32: 98-103.

[44] Ramirez, P., Kelly, J. D. (1998): Traits Related to Drought Resistance in Common Bean. - Euphytica 99: 127-136.

[45] Rosielle, A. A., Hambline, J. (1981): Theoretical aspects of selection for yield in stres and non- stres environment. - CropScience 21: 943-946.

[46] Sayar, M. S. (2017): Additive main effects and multiplicative interactions (AMMI) analysis for fresh forage yield in common vetch (Vicia sativa L.) genotypes. - Agriculture and Forestry 63(1): 119-127.

[47] Sönmez, F., Ülker, M., Yılmaz, N., Ege, H., Bürün, B., Apak, R. (1999): Relationship between grain yield and some yield components in Tir wheat. - Tr. J. of Agric. and Forestry 23: 45-52.

[48] Şahin, M., Göçmen Akçacık, A., Aydoğan, S. (2008): Orta anadolu kuru ve sulu koşulları için tescil edilmiş ekmeklik buğday çeşitlerinin verim ve bazı kalite özellikleri yönünden performanslarının belirlenmesi. - Ülkesel Tahıl Sempozyumu. Konya: 390-400.

[49] Thorne, G. N. (1966): Physiological Aspects of Grain Yield in Cereals. - Growth of Cereals and Grasses. Batter Worths.: 88-106.

[50] TSI. (2015): Türkiye İstatistik Kurumu. - Bitkisel Üretim İstatistikleri, tuik.gov.tr 
[51] Yan, W., Tinker, N. A. (2006): Biplot analysis of multi-environment trial data. Principles and applications. - Canadian Journal of Plant Science 86: 623-645.

[52] Yazar, S., Salantur, A., Özdemir, B., Alyamaç, M. E., Kaplan Evlice, E., Pehlivan, A., Akan, K., Aydoğan, S. (2013): Orta anadolu bölgesi ekmeklik buğday 1slah çalışmalarında bazı tarımsal karakterlerin araştırılması. - Tarla Bitkileri Merkez Araştırma Enstitüsü Dergisi 22(1): 32-40.

[53] Yıldırım, A., Sakin, M. A., Gökmen, S. (2005): Tokat Kazova koşullarında bazı ekmeklik buğday çeşit ve hatlarının verim ve verim unsurları yönünden değerlendirilmesi. - GOÜ. Ziraat Fakültesi Dergisi 22(1): 63-72. 